\title{
Peculiarities of Spring Feeding by Capelin (Mallotus villosus) on the Grand Bank in 1987-90
}

\author{
O. V. Gerasimova \\ Polar Research Institute of Marine Fisheries \\ and Oceanography (PINRO), 6 Knipovich Street \\ 183763, Murmansk, Russia
}

\begin{abstract}
The comparative feeding characteristics of immature and mature capelin (Mallotus villosus) on the Grand Bank (NAFO Divisions 3LNO) during 1987-90 in April and May are presented. Copepods, mainly Calanus finmarchicus, were the main food for immature capelin. Areas of intensive feeding on copepods were the northern and northeastern slopes of the Grand Bank. In addition to copepods, the euphausiid Thysanoessa raschii was a very important prey of mature capelin. Poor feeding on euphausiids by prespawning capelin was partly compensated for by increased predation on juvenile capelin and sandeel. The intensive feeding of capelin on euphausiids and juveniles was observed for several years on the border of NAFO Div. 3L and 30, namely to the south of the Avalon Peninsula. Although little is known about the biology of $T$. raschii on the Newfoundland Grand Bank, its occurrence in the diet of capelin and cod (from a previous study) suggests that in some years it is widely distributed and important in the food chain.
\end{abstract}

Key words: Capelin, food, Grand Bank, juveniles, plankton

\section{Introduction}

The abundance of capelin (Mallotus villosus), like other planktivores with a short life cycle, can fluctuate significantly from year to year. This variability in capelin abundance has the potential to influence the feeding conditions of their main predators and the abundance of their prey, the zooplankton. Through this latter link, the abundance of other planktivores could also be influenced. Since capelin is one of the key elements in the trophic chain, the identification of feeding conditions of capelin could be very important to forecast changes of capelin abundance and the reaction of other elements in the ecosystem.

The dynamics of capelin feeding on the shelves of Newfoundland and Labrador are known in general (Templeman, 1948; Campbell and Winters, 1973; Kovalyov and Kudrin, 1973; Chan and Carscadden, MS 1976). However, there are still few data on the prey spectrum of mature and immature capelin on the Grand Bank.

The feeding of capelin on the Grand Bank from the end of winter to the beginning of the spawning period during 1987-90 is characterized in this paper. An interesting peculiarity of this period is the distinct spatial division of concentrations of young and mature fish, which has been observed from approximately the beginning of April (Campbell and
Winters, 1973). Immature capelin concentrate in the north of the Grand Bank, more often on its northeastern slope in the area of influence of the Labrador Current (Dragesund and Monstad, 1973; Kovalyov and Kudrin, 1973; Mamylov and Bakanev, MS 1984; MS 1985). During their prespawning migrations, mature fish shift into warmer and fresher coastal waters, as well as into the area of the Southeast Shoal (Campbell and Winters, 1973). There are data on differences in the characteristics of daily vertical migrations; young fish, concentrating into small schools, are in the water column during daytime, whereas prespawning capelin form dense concentrations in near bottom layers (Mamylov and Bakanev, MS 1984). These differences could significantly influence the prey spectrum of mature and immature fish.

\section{Materials and Methods}

Capelin for this study were collected by midwater trawl during trawl acoustic surveys in 1987-90 in April and May in NAFO Div. 3LNO. General observations of prey content in capelin stomachs were determined in all years while a quantitative weight analysis was conducted during 1988 and 1989 (Table 1).

Field analysis of feeding was conducted using a maximum of 50 specimens from each catch. Fork length, weight and sex of each fish were determined. 
TABLE 1. Number of samples used in capelin feeding studies.

\begin{tabular}{lcc}
\hline \hline & \multicolumn{2}{c}{ Number of stomachs } \\
\cline { 2 - 3 } Year & Field analysis & Quantitative weight analysis \\
\hline 1987 & 1355 & - \\
1988 & 1612 & 265 \\
1989 & 2270 & 194 \\
1990 & 1418 & - \\
\hline
\end{tabular}

Stages of gonad maturity were classified as immature or mature. The prey species of all important taxa in the stomach contents were recorded. A measure of stomach fullness was estimated using a 5-stage scale.

Quantitative weight analysis was carried out in a laboratory on stomachs preserved in $4 \%$ formalin solution. Stomach contents were examined under a binocular microscope. Fish larvae, euphausiids, hyperiids and large copepods were identified to species when possible, and other organisms to larger taxonomic units. Special attention was given to estimation of abundance and lengths of prey. Total lengths of all prey items, except copepods, larval Cirripedia and pteropods, were measured and these measurements were used for reconstruction of weights of food organisms (Table 2). Total weights in the samples of larval Cirripedia and pteropods were derived by counting the individuals and multiplying by the mean weights per individual reported by Bogorov (1934) and Petipa (1957), respectively. For copepods, individuals were separated by maturity stage, their lengths measured and individual weights derived by a length-weight regression (Kanayeva, 1962). Total weight per sample was then calculated by multiplying by total numbers of individuals.

The results from the field analysis were analyzed separately for immature and mature capelin, which were divided into $1 \mathrm{~cm}$ size groups (Fig. 1). Frequency of occurrence of individual prey (i) was determined in each size group by results of the field analysis, using three criteria:

a) $F_{i 1}$ - the ratio of number of stomachs containing prey $\mathrm{i}$ in relation to the number of stomachs with food;

b) $F_{i 2}$ - the ratio of number of stomachs containing prey $\mathrm{i}$ in relation to the number of all investigated stomachs, including empty ones;

c) $\mathrm{F}_{\mathrm{i} 3}$ - the ratio of number of stomachs containing prey $i$ in relation to the total number of records of food.
The total index of food consumption was used to determine capelin feeding intensity. Traditionally this value is calculated as the ratio of reconstructed food weight to fish weight and presented as per mille (\%oo). The data of field and quantitative weight analysis were combined in this paper and the total index of food consumption was calculated on the formula:

$$
l_{j}=\frac{\sum_{i=1}^{n} \rho_{i j} F_{i j 1}}{P_{j}}
$$

where $F_{i j 1}$ is the frequency of occurrence of prey $i$ in the stomachs of capelin from size group $j, \rho_{i j}$ is the average weight of prey $i$ in a stomach of specimen j, determined by results of the quantitative weight analysis as the ratio of total weight of prey $i$ in the stomachs to the number of stomachs, containing this prey, $\mathrm{n}$ is the total number of prey taxa in the diet of size group $j, P_{j}$ is the mean weight of specimen $\mathrm{j}$.

\section{Results}

\section{Main prey of capelin in spring}

Copepods, euphausiids and juvenile fish were the most important prey for capelin in spring on the Grand Bank (Table 3).

Copepods were the important food item for the whole population of capelin and especially immature fish. The Arcto-boreal species, Calanus finmarchicus, occurred most often. In spring 1988, when copepods were of greatest importance to immature capelin, about one-third of the stomach content weight consisted of representatives of the Arctic complex of zooplankton, mainly Calanus hyperboreus and Metridia longa. In the Northwest Atlantic, this complex is associated with Labrador Current waters (Jones, 1969; Vladimirskaya, 1973). Small neritic copepods Temora longicornis, Pseudocalanus minutus and Centropages hamatus were found in only very small amounts in the stomachs of capelin.

Meganyctiphanes norvegica and Thysanoessa raschii were the two euphausiids in the diet of capelin, with the latter playing the leading role. Thysanoessa raschii was present in the diet of fish of all sizes, however, the importance of this prey species was much higher for mature capelin even when mature and immature fish of the same size were compared (Fig. 2). The length of crustaceans, consumed by capelin varied from 12 to $22 \mathrm{~mm}$.

Juveniles of sandeel 10-13 $\mathrm{mm}$ long and juveniles of capelin 40-68 mm long were the juvenile fish consumed by capelin, however, they were con- 
TABLE 2. The parameters of equations relating length $(\mathrm{L}$ in $\mathrm{cm})$ and weight $(\mathrm{W}$ in $\mathrm{g})$ of main food items of capelin: $W=a L^{b}$

\begin{tabular}{llll}
\hline \hline Food items & \multicolumn{1}{c}{$\mathrm{a}$} & $\mathrm{b}$ & \multicolumn{1}{c}{ Source } \\
\hline Parathemisto gaudichaudi & 0.05 & 2.42 & Strelnikova, 1989 \\
Parathemisto libellula & 0.01994 & 2.811 & Berestovsky et al., 1989 \\
Thysanoessa raschii & 0.0067 & 2.712 & Berestovsky et al., 1989 \\
Meganyctiphanes norvegica & 0.00923 & 3.125 & Berestovsky et al., 1989 \\
Sagitta elegans & 0.00117 & 3.0 & Berestovsky et al., 1989 \\
Oikopleura labradoriensis & 0.041 & 1.868 & Plekhanova, pers. comm. \\
Capelin juveniles & 0.0000612 & 3.955 & Our data \\
Sand eel juveniles & 0.00196 & 3.179 & Berestovsky et al., 1989 \\
\hline
\end{tabular}

The length of hyperiids was measured from the base of antennae to the end of telson, the length of euphausiids - from the first edge of eye to the end of telson, the length of appendicularians - as body length (without tail), the length of chaetognaths and fish juveniles - as total body length.

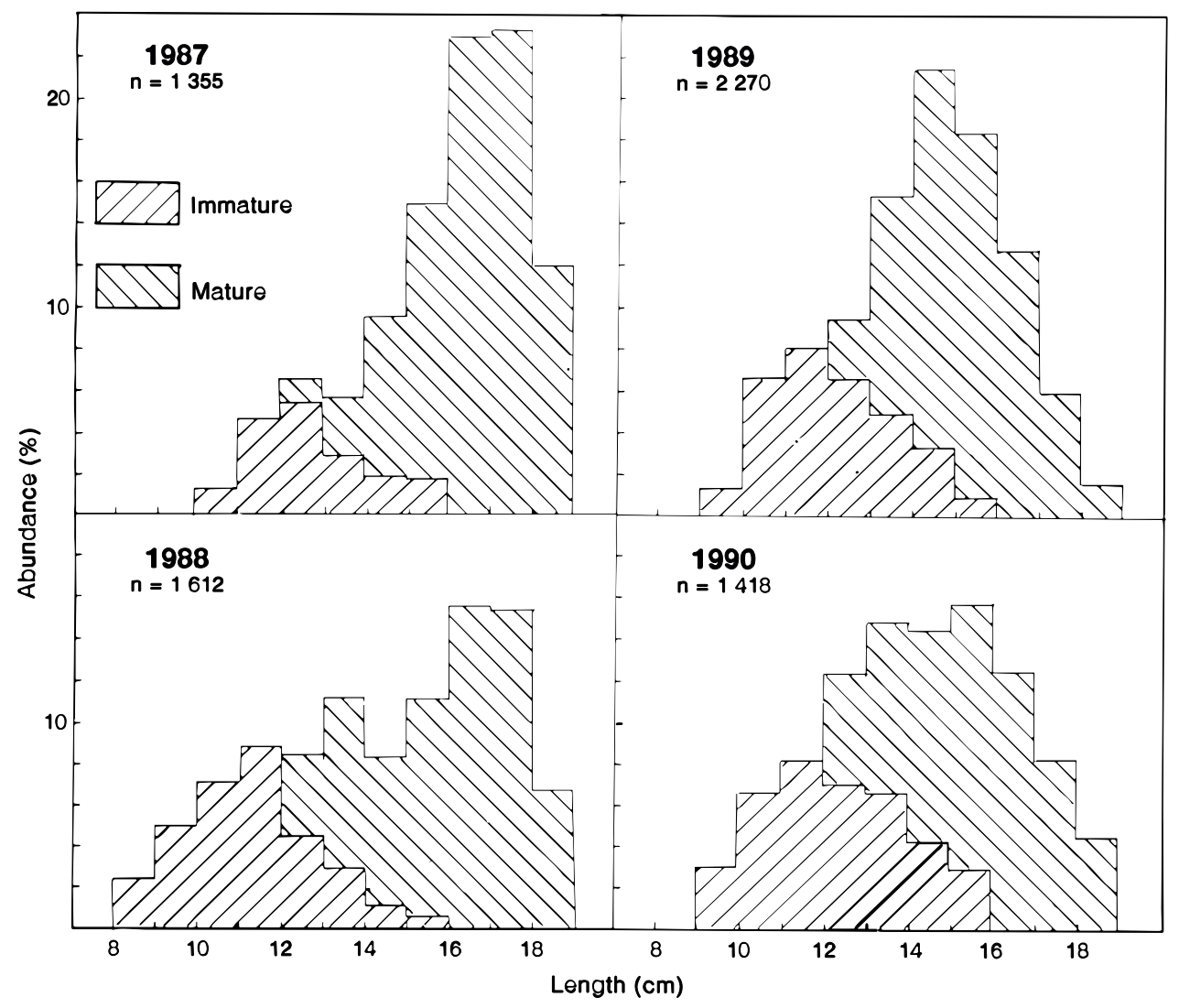

Fig. 1. Size composition of capelin taken for the field analysis of feeding by capelin on the Grand Bank in April/May, 1987-90.

sumed only by mature capelin. According to these data, it would appear that these juvenile fish are an alternative food for euphausiids; the frequency of occurrence of juveniles increases in years with low occurrence of euphausiids in the diet of mature capelin.
The role of hyperiids in spring feeding of capelin was not important compared with summer/autumn feeding in Div. 2J3K (Chan and Carscadden, MS 1976). A group of "other crustaceans" consisted of gammarids, mysids and larvae of Cirripedia which were probably only occasional food items. Of the 
TABLE 3. Frequency of occurrence $\left(F_{i 1}, \%\right)$ of food items in the stomachs of immature and mature capelin in April-May, 1987-90.

\begin{tabular}{|c|c|c|c|c|c|c|c|c|}
\hline \multirow[b]{2}{*}{ Food items } & \multicolumn{2}{|c|}{1987} & \multicolumn{2}{|c|}{1988} & \multicolumn{2}{|c|}{1989} & \multicolumn{2}{|c|}{1990} \\
\hline & Immature & Mature & Immature & Mature & Immature & Mature & Immature & Mature \\
\hline Copepoda & 58.5 & 39.2 & 87.1 & 47.5 & 68.2 & 39.3 & 33.6 & 52.3 \\
\hline Euphausiacea & 15.9 & 30.7 & 1.9 & 14.6 & 8.8 & 35.9 & 4.4 & 28.2 \\
\hline Hyperiidea & 3.5 & 4.2 & 5.7 & 19.4 & 7.8 & 11.5 & 0 & 3.4 \\
\hline Other crustacea & 2.1 & 12.8 & 7.8 & 0.5 & 4.9 & 6.8 & 4.6 & 7.6 \\
\hline Limacina sp. & 0 & 0 & 6.8 & 1.6 & 0.3 & 0.1 & 2.3 & 8.5 \\
\hline Oikopleura labradoriensis & 2.4 & 11.4 & 8.0 & 5.1 & 15.2 & 5.3 & 12.1 & 12.8 \\
\hline Sagitta elegans & 0.7 & 5.0 & 1.6 & 4.6 & 1.1 & 5.9 & 0.9 & 10.5 \\
\hline Fish juveniles & 0 & 13.3 & 0 & 18.7 & 0 & 11.1 & 0 & 4.9 \\
\hline Ctenophora & 0.3 & 4.4 & 0.2 & 4.7 & 0.1 & 3.5 & 0.2 & 0.9 \\
\hline Empty stomachs (\%) & 23.2 & 15.9 & 11.7 & 16.0 & 24.0 & 20.5 & 50.7 & 21.9 \\
\hline Total number & 289 & 1114 & 512 & 1100 & 717 & 1553 & 526 & 873 \\
\hline
\end{tabular}

non-crustacean zooplankton, Oikopleura labradoriensis, which is a component of the Arctic zooplankton, and Sagitta elegans, which dwells predominantly on shallow waters (Plekhanova and Ryzhov, MS 1976), played notable roles in the feeding patterns of capelin. The latter prey was more often found in the diet of mature capelin.

\section{Spatial character of feeding}

The spring distribution of capelin in their main feeding areas were found to be influenced by the biology of capelin and the spatial structure of the plankton community of the Grand Bank. Copepods were actively consumed by capelin in the north of the bank, however, in some years (in 1988, for example) the border of the copepod feeding area shifted to the south (Fig. 3).

The intensive spring feeding of capelin on euphausiids was observed for several years near the southern coast of the Avalon Peninsula on the border of NAFO Div. 3L and 30. In 1989, when consumption of euphausiids was the highest, capelin fed on them within the wide area of the central shallow bank.

In spite of the interannual changes of the feeding areas, the areas of feeding on euphausiids and copepods generally did not overlap. The areas of the most active feeding on fish juveniles were to the south of the Avalon Peninsula, and partly coincided with areas of feeding on euphausiids.

\section{Intensity of spring feeding}

Feeding intensity was assessed by examining two parameters: (a) the proportion of empty stomachs and (b) a measure of stomach fullness.

In immature capelin the percentage of empty stomachs varied between years from $11.7 \%$ in 1988 to $50.7 \%$ in 1990 , while for mature fish the range was narrower from $15.9 \%$ in 1987 to $21.9 \%$ in 1990 .

It was possible to observe the asynchronous fluctuations of spring feeding intensity in immature and mature capelin by the changes of indices of food consumption (Fig. 4) representing a measure of stomach fullness. In 1988, the year for most intensive spring feeding by immature fish, the mean index of food consumption constituted 118\%oo and the subsequent year it was 1.5 times lower at $75 \%$. Mature fish fed on euphausiids poorly in 1988 and the mean index of food consumption constituted 92\%oo. In 1989, consumption of euphausiids was maximum, and mean index of food consumption increased more than 1.5 times to $152 \%$ ooo.

\section{Discussion}

The results permit us to document for the first time the prey spectrum of immature and mature capelin on the Grand Bank during the spring. Immature capelin, which tended to remain over the northern and northeastern areas, fed heavily on copepods. Mature capelin which tended to migrate into the western part of the region, especially near the Div. 3L and Div. 30 border, also preyed heavily on copepods, as well as euphausiids. Predation on euphausiids by mature capelin showed annual variability and when euphausiid consumption was low, the intake of juvenile capelin and sandeels increased.

The results also indicated that the species composition of copepods, in the diet of capelin in spring, was represented by small neritic species, large Arctic species and Arcto-boreal Calanus finmarchicus. The small neritic copepods were not important in the diet of capelin, and the proportion of large 


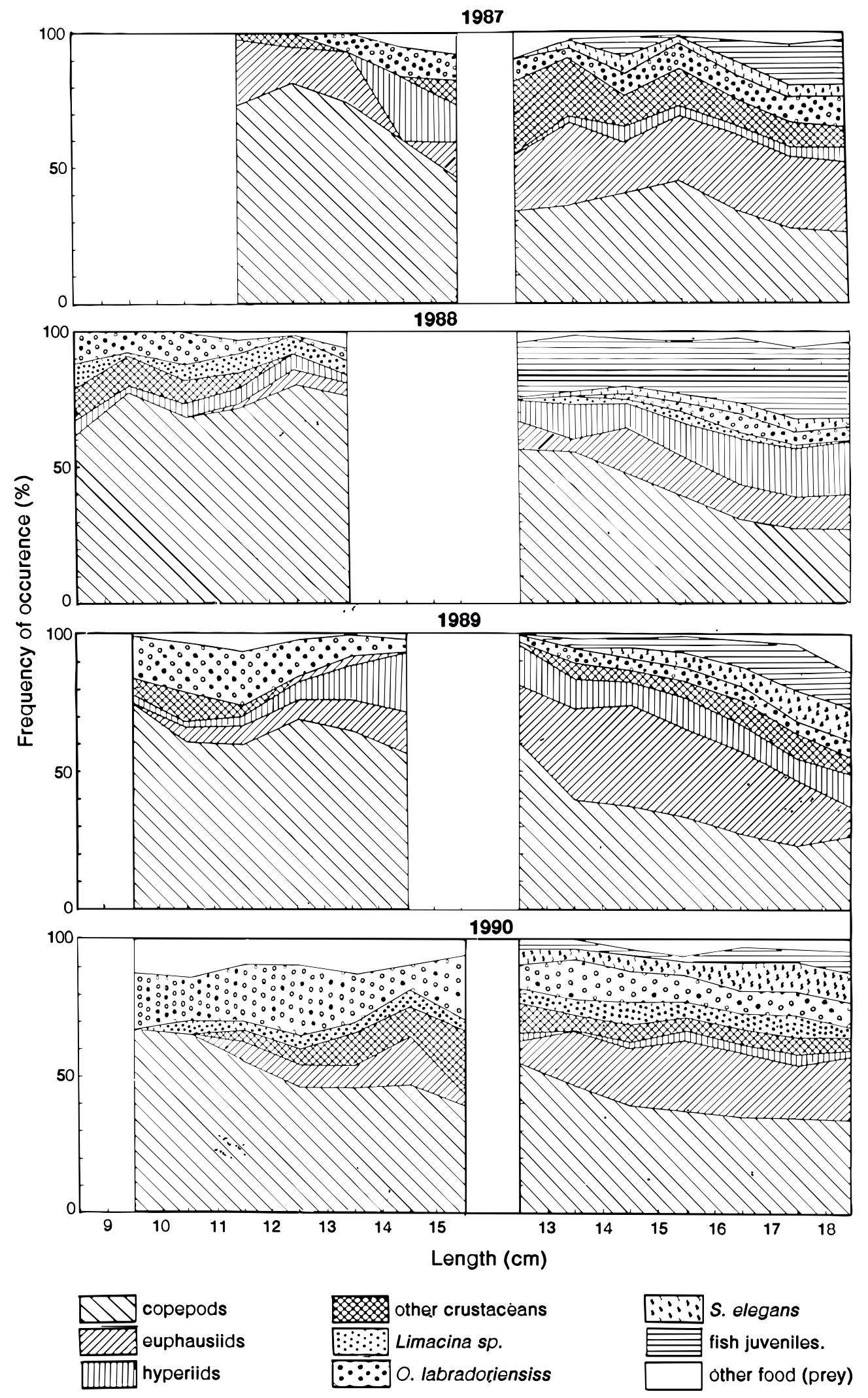

Fig. 2. Frequency of occurrence of various food items $\left(F_{i 3}\right)$ in stomachs of immature (left) and mature (right) capelin on the Grand Bank in April/May, 1987-90. 


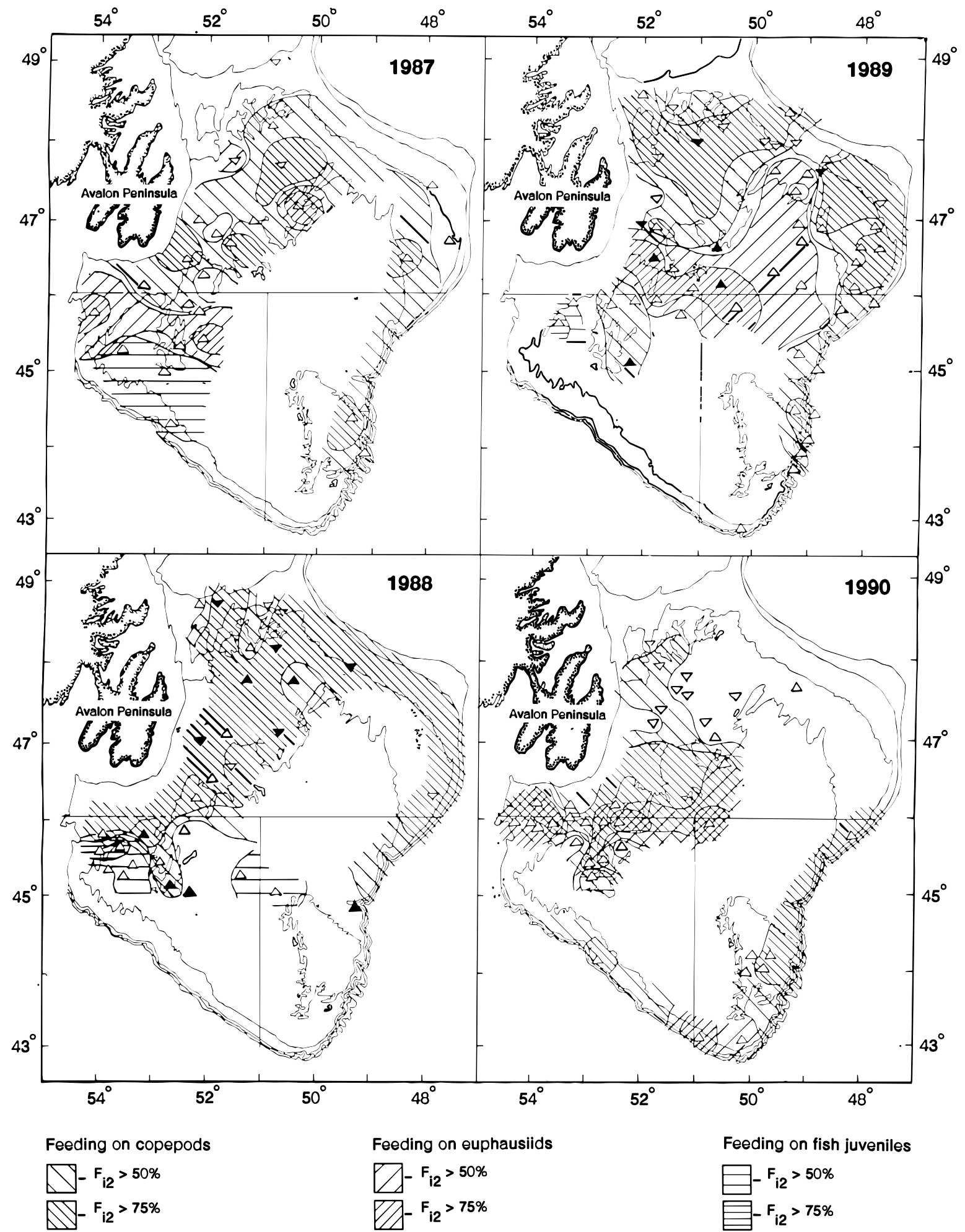

Places of sampling for the field analysis

$\nabla$ - immature capelin constitute $>50 \%$ of a catch

$\triangle$ - mature capelin constitute $>50 \%$ of a catch

V- Places of sampling for quantitative weight analysis

Fig. 3. Main areas of capelin feeding of the Grand Bank in 1987-90. 


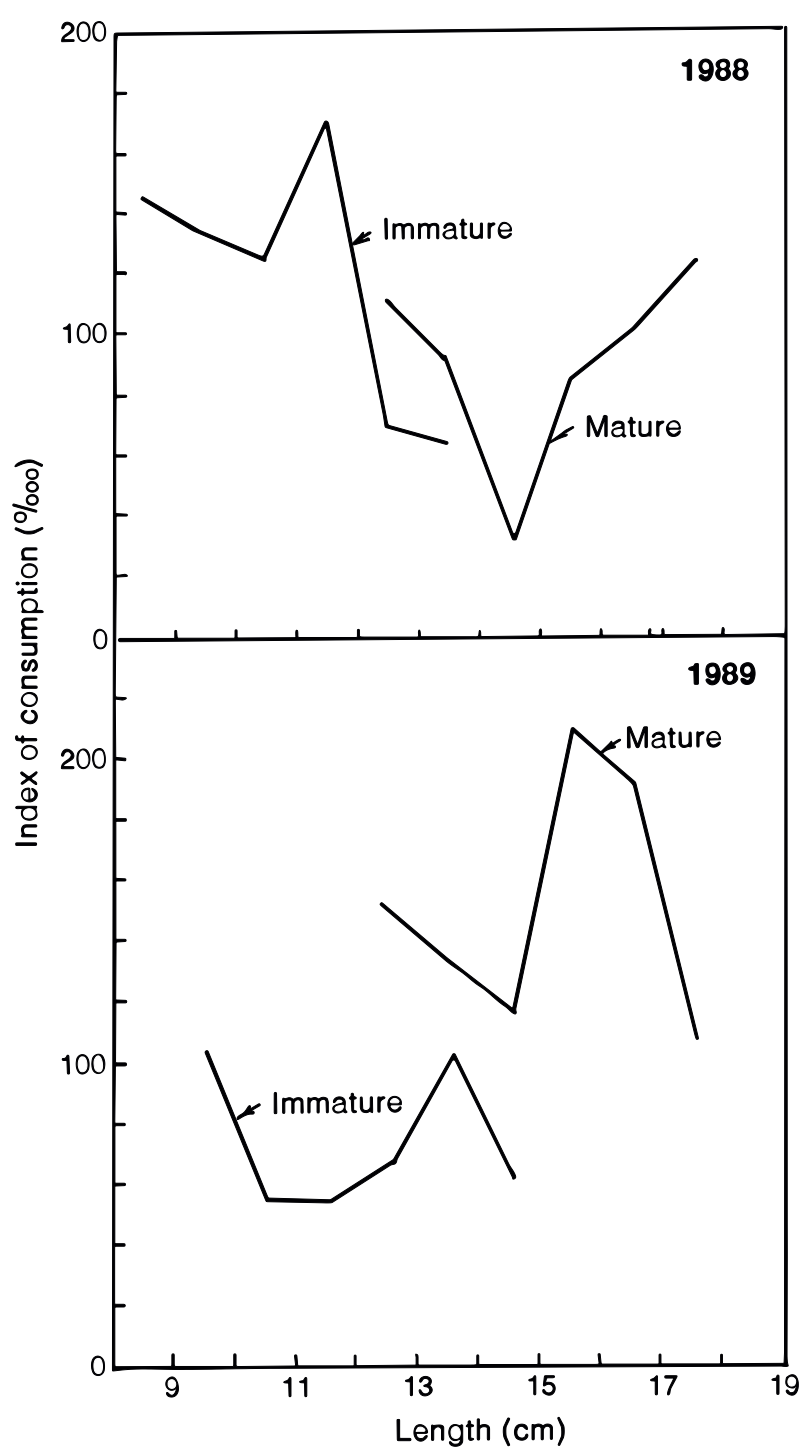

Fig. 4. Indices of food consumption by immature and mature capelin on the Grand Bank in April/May, 1988 and 1989.

Arctic copepods in the diet probably fluctuated depending on the hydrological conditions and hence their occurrence in the area. Successful spring feeding of capelin, especially the immature ones, was closely connected with abundance of C. finmarchicus. This species is always found in the composition of spring zooplankton on the Grand Bank and dominates in abundance on slopes in the areas of hydrological fronts (Kamotskaya and Plekhanova, 1975; Plekhanova and Ryzhov, MS 1976).

Long-term data show that the period of occurrence of $C$. finmarchicus in zooplankton of the
Grand Bank is rather stable, although there are interannual fluctuations in both timing and abundance (Robinson et al., 1975). During the winter C. finmarchicus concentrate at depths greater than $200 \mathrm{~m}$ and sometimes deeper than $1000 \mathrm{~m}$ (Sushkina, 1962). Periods of their spring ascent from the deeper waters and their reproduction near the surface depend on the increase in surface water temperatures. In cold years, the spring intensive feeding on copepods by immature capelin is likely to occur later, since there appears to be a relationship between the abundance of $C$. finmarchicus in the surface waters in May and mean water temperatures in the upper $50 \mathrm{~m}$ (N. V. Plekhanova, PINRO, Murmansk, pers. comm.). The maximum abundance of $C$. finmarchicus in spring has been registered on the northern and northeastern slopes of the Grand Bank (Plekhanova and Ryzhov, MS 1976) and this area has been reported as the main feeding area for immature capelin in spring (Campbell and Winters, 1973; Jangaard, 1974).

The abundance of euphausiids in the composition of zooplankton of the Grand Bank fluctuates considerably between years in contrast with copepods (Robinson et al., 1975). In spite of the fact that several species of euphausiids occur in this area, capelin almost exclusively consumed $T$. raschii. The same phenomenon has been observed in the Gulf of St. Lawrence, where four species of euphausiids occur (Berkes, 1976; Vesin et al., 1981).

It is possible that some peculiarities of the biology of $T$. raschii make it the favoured food of capelin. Thysanoessa raschii is a glacio-neritic species (Beklemishev, 1969) able to survive under low temperature and salinity. This species is usually found in relatively shallow water $(<150 \mathrm{~m})$ (Drobysheva, 1985; Berkes, 1976). Since it is predominantly a herbivore (Ponomareva, 1990; Berkes, 1976) it can form dense concentrations, whereas predacious euphausiids are usually dispersed (Ponomareva, 1990). During the winter, T. raschii concentrates near the bottom of relatively shallow areas, not deeper than $100 \mathrm{~m}$ in the Barents Sea, and only in the shallow Anadyr Bay of the Bering Sea (Ponomareva, 1990).

In spring during their spawning period, T. raschii form dense concentrations over large areas in surface waters over their overwintering zones. The concentrations are stable during several days (Ponomareva, 1990). Based on the occurrence of T. raschii in substantial quantities in cod stomachs, Lilly and Rice (MS 1983) suggested that these prey probably swarm and undertake diel migrations which take them close to the bottom. 
Geographically, euphausiids are important in the diet of prespawning capelin in several areas. In the Barents Sea, where euphausiids are a stable and abundant component of zooplankton, their proportion in the diet of capelin reaches $87.1-89.7 \%$ by weight in February-May (Panasenko, MS 1984). In the Gulf of St. Lawrence, mature capelin feed mainly on euphausiids in spring, while hyperiids and fish juveniles do not play a great role in the diet in spite of their abundance in plankton (Vesin et al., 1981).

The proportion of euphausiids in the diet of prespawning capelin on the Grand Bank fluctuated considerably between years. However, since there is so little known on the population dynamics of T. raschii on the Grand Bank, it is not possible to explain fluctuations in the capelin diet on the basis of zooplankton abundance. In years of low predation on euphausiids, this lack was compensated by consuming other prey, predominantly fish juveniles. Judging by the low indices of food consumption in 1988, it may be hypothesized that other prey can not completely replace euphausiids in the spring feeding of mature capelin.

Feeding by capelin was clearly heavy during the spring period and this raises the question of the importance of this activity on population parameters such as growth, maturation and migration. Evidently immature capelin have a close trophic link with copepods in spring, and any deviation in development of the latter influences the intensity of capelin feeding. Mature capelin are able to compensate for poor feeding on main prey species by consuming others, i.e. their trophic links may be more labile in spring, and the intensity of feeding may be more stable. On the other hand, immature capelin may be able to compensate for the lack of food in spring by more active feeding in summer and autumn. Although our data did not permit evaluation of these influences, inferences can be drawn from other observations. Other authors (Winters, 1970; Jangaard, 1974) have noted that fat content of immature fish is low after the overwintering period and does not change during spring feeding. Furthermore, in spite of active feeding, fat content and body weights of mature capelin, do not increase. In the Barents Sea, the ratio between immature and mature fish is determined by the fat content of the muscles and this process occurs during September-October, well before the March-May spawning period (Oganesyan and Dvinin, 1988). Based on these observations, we suggest that for mature capelin, spring feeding on the Grand Bank is probably more important for gonad maturation than for growth. Although Winters (1970) did not observe significant increases in fat content during spring feeding, Borisov and Dvinin (1986) noted that the specimens with lowest fat content in the tissue died first after spawning. This implies that the intensity of feeding may also contribute to post-spawning survival.

Any possible link between feeding and migration would require extensive directed research to identify annual changes in zooplankton abundance and areas of occurrence, along with detailed knowledge of migration patterns offshore. It may be that if food is important for gonad development, changes in prey (mainly euphausiids) distribution would also result in changes in migration routes from the offshore to the coastal areas. It is also possible that changes in zooplankton dynamics and capelin migration are interrelated with the oceanography of the region. Thus, future studies to identify factors influencing capelin migration patterns should require an integrated biological approach including physical oceanography.

\section{References}

BEKLEMISHEV, K. V. 1969. Ecology and biogeography of the open Ocean. M., "Nauka", 291 p. (in Russian).

BERESTOVSKY, E. G., K. A. ANISIMOVA, S. G. DENISENKO, E. N. LUPPOVA, V. M. SAVINOV, and S. F. TIMOFEEV. 1989. Relationship between size and body weight of some invertebrates and fish from the North-East Atlantic. Appatity, 23 p. (in Russian).

BERKES, F. 1976. Ecology of euphausiids in the Gulf of St. Lawrence. J. Fish. Res. Board. Can., 33: 18941905.

BOGOROV, W. G. 1934. The biomass of plankters. Bull. $V N I R O$, no. 1. (in Russian).

BORISOV, V. M., and Yu. F. DVININ. 1986. Some biological indices and attempt of their utilization to estimate the Barents Sea capelin natural mortality. In: Dynamics of commercial fishes abundance. M., "Nauka", p. 131-141. (in Russian).

CAMPBELL, J. S., and G. H. WINTERS. 1973. Some biological characteristics of capelin, Mallotus villosus, in the Newfoundland area. ICNAF Redbook, 1973 (III): 137-144.

CHAN, M., and J. E. CARSCADDEN. MS 1976. The food and feeding of capelin (Mallotus villosus) in the Labrador area during autumn 1973. ICNAF Res. Doc., No. 20, Serial No. 3800, 5 p.

DRAGESUND, O., and T. MONSTAD. MS 1973. Observations on capelin (Mallotus villosus) in Newfoundland waters. ICNAF Res. Doc., No. 33, Serial No. 2967, $7 \mathrm{p}$.

DROBYSHEVA, S. S. 1985. The euphausiids. Their significance in the plankton community, zoogeography, populational structure, life cycles and dynamics of abundance of numerous species. In: Life and condition of its existing in pelagial of the Barents Sea. Appatity, p. 162-173. (in Russian)

JANGAARD, P. M. 1974. The capelin (Mallotus villosus): biology, distribution, exploitation, utilization and composition. Bull. Fish. Res. Board. Can., 186: 70 p.

JONES, L. T. 1969. Continuous plankton records: studies on the zooplankton east of Newfoundland and Labrador, with particular reference to the euphausiids Thysanoessa longicaudata (Krøyer). Bull. Mar. Ecol., 6: $275-300$. 
KAMOTSKAYA, L. E., and N. V. PLEKHANOVA. 1975. Distribution of zooplankton on the Great Newfoundland and Flemish Cap banks depending on thermal conditions. Tr. PINRO, Murmansk, 35: 113-120.

KANAYEVA, I. P. 1962. Mean weight of Copepoda in Central and North Atlantic, Norwegian and Greenland Seas. Tr. PINRO,Murmansk, 46: 253-266. (in Russian).

KOVALYOV, S. M., and B. O. KUDRIN. 1973. Soviet investigations on capelin in the Northwest Atlantic in 1971 and 1972. ICNAF Redbook, 1973 (III): 121-126.

LILLY, G. R., and J. C. RICE. MS 1983. Food of Atlantic cod (Gadus morhua) on the Northern Grand Bank in spring. NAFO SCR Doc., No. 87, Serial No. N753, 35 p.

MAMYLOV, V. S., and V. S. BAKANEV. MS 1984. An acoustic assessment of capelin stocks in NAFO Div. 3LNO and $2 \mathrm{~J}+3 \mathrm{~K}$ in 1983. NAFO SCR Doc., No. 39, Serial No. N824, 4 p.

MS 1985. Soviet investigations of capelin schools in Divisions 3LNO in May-June 1984. NAFO SCR Doc., No. 55, Serial No. N1004, 6 p.

OGANESYAN, S. A., and Yu. F. DVININ. 1988. Relationship between rate of maturation and intensity of fat accumulation in fish (as example - Barents Sea capelin). In: Ecology, biological production and problems in mariculture of the Barents Sea. Murmansk, $p$. 186-188. (in Russian).

PANASENKO, L. D. MS 1984. Feeding of the Barents Sea capelin. ICES C.M. Doc., No. H:6, p.

PETIPA, T. S. 1957. On mean weight of the main forms of the Black Sea zooplankton. Proceeding of Biological Station (Sevastopol). Vol. 9 (in Russian).
PLEKHANOVA, N. V., and V. M. RYZHOV. MS 1976. Plankton development in the Newfoundland banks areas in June 1975. ICNAF Res. Doc., No. 69, Serial No. 3872, $6 \mathrm{p}$.

PONOMAREVA, L. A. 1990. Biology of the World Ocean's euphausiids. M., "Nauka", 213 p. (in Russian).

ROBINSON, G. A., J. M. COLEBROOK, and G. A. COOPER. 1975. The continuous plankton recorder survey: plankton in the ICNAF area, 1961-71, with special reference to 1971. ICNAF Res. Bull., 11: 6171.

STRELNIKOVA, V. M. 1989. Relationship between weight and length of body and calorie content of Antarctic hyperiids Parathermisto gaudichaudi. Hydrobiol. Journ., 25(1): 107-109. (in Russian).

SUSHKINA, A. R. 1962. The vertical migrations and daily feeding rhythm of Calanus finmarchicus (Gunn) in connection with its age and fitness. Tr. VNIRO, Moscow, 46: 235-252. (in Russian).

TEMPLEMAN, W. 1948. The life history of the capelin (Mallotus villosus Müller) in Newfoundland waters. Bull. Nfld. Gov. Lab., 17: 151 p.

VESIN, J. P., W. C. LEGGETT, and K. W. ABLE. 1981. Feeding ecology of capelin (Mallotus villosus) in the estuary and western Gulf of St. Lawrence and its multispecies implications. Can. J. Fish. Aquat. Sci., 38: 257-267.

VLADIMIRSKAYA, E. V. 1973. The qualitative composition of zooplankton of the Northwest Atlantic. Tr. VNIRO, Moscow, 84(4): 63-80 (in Russian).

WINTERS, G. H. 1970. Biological changes in coastal capelin from the over-wintering to the spawning conditions. J. Fish. Res. Board Can., 27: 2215-2224. 
